\title{
A Theoretical Model to Measure Managerial and Leadership Competence of Business School Managers
}

\author{
A. Shaikh, ${ }^{*}$ C.A. Bisschoff, C.J. Botha \\ Regent Business School, Durban, South Africa \\ NWU School of Business and Governance, North-West University, South Africa \\ Christo.bisschoff@nwu.ac.za
}

\begin{abstract}
A theoretical model to measure managerial competence was developed by evaluating two previous models with similar aims. In addition to the original eight management competencies, another eight competencies were identified and applied to determine the management competencies needed in the Fourth Industrial Revolution with its fast-changing business environment. The article narrows down eleven management competencies and develops measuring criteria for each; in total 42 criteria. The eleven business competencies are leading change, cultural intelligence, team building, conflict management, communication skills, a global leader mindset, emotional intelligence, career awareness, personal value system, and external and ethical influences. The model is a theoretical model and presents management competencies relevant to the modern business environment. The value of this study resides in a strong theoretical basis for postmodern business environmental skills that managers need to maintain completeness of their organizations as well as providing a sound point of departure for other researchers of managerial competence.
\end{abstract}

Keywords: Competence, skills, management, leadership, model

\section{Introduction}

"The global economy stands on the brink of a technological revolution that will fundamentally alter the way we live, work, and relate to one another. In its scale, scope, and complexity, the transformation will be unlike anything humankind has experienced before. We do not yet know just how it will unfold, but one thing is clear: the response to it must be integrated and comprehensive, involving all stakeholders of the global polity, from the public and private sectors to academia and civil society."

(Schwab, 2016).

Schwab (2016), in his address at the World Economic Forum Annual Meeting, refers to the influence of the Fourth Industrial Revolution on the global economy. This revolution is characterized by a fusion of technologies that is blurring the lines between the physical, digital, and biological spheres. The speed of current scientific breakthroughs has no historical precedent, and the breadth and depth of these changes herald the transformation of entire systems of production, management, and governance (Manyika, 2017). Moreover, the Fourth Industrial Revolution has disrupting almost every industry in every country. Manyika (2017) goes on to argue that these technologies also raise difficult questions about the broader impact of automation of jobs, skills, wages, and the nature of work itself. The opportunities and challenges that originate from the technologies enabled development of automation, such as robotics and artificial engineering, brings the promise of higher productivity, increased efficiencies, safety and convenience. For policymakers, business leaders, managers and workers at large, these shifts create considerable uncertainty alongside with the potential benefits.

The Fourth Industrial Revolution has the potential to raise global income levels and improve the quality of life for populations around the world. In the future, technological innovation will also lead to a supply-side miracle, with long-term gains in efficiency and productivity. Transportation and communication costs will drop, logistics and global supply chains will become more effective, and the cost of trade will diminish, all of which will open new markets and drive economic growth (Brynjolfssen \& McAfee, 2014:12). At the same time, however, these authors have pointed out that the revolution could yield greater inequality, because it has the potential to disrupt labor markets particularly. Here Schwab (2016) argues that in the future, talent, more than capital, will represent the critical factor of production. This will increasingly segregate the job market into clear segments where low-skills earn low pay, and high skills earn high pay. A key challenge, therefore, to most organizations today, both public and private, is the demand to deal with the acceleration of innovation and the velocity of disruption where management strategy becomes a continuous activity that also includes constant mission adjustments (Anderson, 2017). Here for those in leadership and management roles, 
this translates into a need to upgrade their knowledge and skills constantly. In turn, this means that organizations must be able to target knowledge and skills training accurately, quickly and cost-effectively. In this context, it is imperative for organizations to develop a comprehensive framework that delineates a distinct hierarchy of skills and knowledge, or competencies, needed by managers in an organization.

Problem Statement: Business managers are faced with the globalization of business, rapid technological change, constant re-organizing and competence-based competition (Botes, 2014:145). These developments challenge their skills, competencies and capabilities. Here Daft and Marcic (2016:76) argue that the performance culture in a business largely depends on the effectiveness of its managers to establish a performance-driven attitude among employees within the challenging environment they operate in. Globalization has also created the demand for global leadership competencies among business leaders. This, in turn, has made the development of global leadership competencies a crucial measure of any business education program in the $21^{\text {st }}$ century (Cumberland \& Alagaraja, 2016). The modern global business environment, as described by Walker and Schmitz (in Katulwa, 2016:65), consists of a series of complex, interdependent developments which include unyielding competitive pressures, rapid market shifts, major acquisitions or mergers, the lowering of trade barriers, decreasing transport costs, heightened expectations on the part of customers and employees, advances in communication and information technology, global access to capital markets and inflation-driven staff reductions. Hitt and Ireland stated, back in 2005, that the knowledge economy was perceived as being complex, challenging and filled with competitive opportunities and threats (Katulwa, 2016:27). The turbulence and complexity carried forward from the 1980s and 1990s culminated into a "new competitive landscape" where the business environment was unpredictable and constantly changing. This changing business environment demands changing roles for business managers and leaders; hence the need for a new set of competitive capabilities.

In an attempt to gauge competencies, Tubbs and Schulz (2006:489) developed the taxonomy of global leadership competencies upon which leadership development efforts could be focused. This taxonomy of leadership and meta-competencies included teamwork and fellowship, understanding the big picture, attitude is everything, leadership as the driving force, innovation and creativity, communication of the leader's voice and, leading change. Just before these researchers, McCauley and Van Velsor (2004:13-15) identified and studied several leadership challenges that should be incorporated in management education and leadership development. Their challenges included leading diverse teams, being adaptable to the changing world of work, transferring knowledge and coaching subordinates, encouraging collaboration and communication, and dealing with complexity. This study was carried out by their Center for Creative Leadership (CCL) among African managers. Today, managerial challenges and required competencies are more under the microscope as a result of the rapidly shifting dynamics of the management and leadership environments across all sectors of the global economy coupled with profound diversity and complexity in the context of the Fourth Industrial Revolution (Manyika, 2017). This has framed the problematic of changing skills and competencies for modern managers and leaders. What skills do they really need in this fastchanging business environment to keep abreast of the challenges they face?

Objectives: The primary objective of this article is to develop a theoretical model to measure skills for managerial and leadership competence.

The following secondary objectives address the primary objective:

- Perform a theoretical study on existing model(s) to measure managerial competence;

- Identify the skills required for managerial and leadership competence;

- Identify the criteria required to measure each managerial or leadership skill from the literature study; and to

- Compile a questionnaire to measure each of the skills for managerial competence.

\section{A Selected Theoretical Model to Measure the Skills For Managerial and Leadership Competence:}

The theory builds on two existing studies performed by Thekiso (2011) and Shaikh (2013) who attempted to address managerial competence challenges at business schools. These authors developed skills models which are used here as a point of reference. 
Overview: The selected model represents the results of a study to measure the skills for the managerial competence of MBA managers educated by private business schools in South Africa at their KwaZulu-Natal and Gauteng campuses. The original model pictured by Thekiso (2011) identified seven identified skills identified from a detailed literature review on managerial competence. After the theoretical construction of the model, Thekiso (2011) proceeded to empirically test his hypothesized model by gathering data from a sample of 395 part-time Master of Business Administration (MBA) students from three business school campuses of the North-West University (Mafikeng, Potchefstroom and Vanderbijlpark).The results indicated marginal success because the majority of the managerial skills were either borderline reliable or unreliable. Only two skills were reliable with a Cronbach Alpha coefficient exceeding 0.70 (excellent); three skills exceeded 0.57 (minimum reliability level for the study) but had Alpha coefficients below the desired 0.70, while two skills were unreliable (falling below the 0.57 lower margin of reliability) (Field, 2009:668). The two unreliable skills (Leading skills and Organizing skills) are, therefore, less likely to represent themselves in repetitive studies of a similar nature; this signifies a warning in the possible future applications of the model to measure managerial competence. In addition to the low reliability coefficients, a number of measuring criteria also had to be discarded due to low or dual-loading characteristics. The unsatisfactory results forced Thekiso (2011:174) to conclude that his model has failed.

Then in 2013, the model initially developed by Thekiso, was re-evaluated by Shaikh (2013) to determine if the strong theory of Thekiso does have promise and if the model can be amended and operationalized. Success would mean that the model (or parts of it) could be useful in another business school educated manager sample to measure their managerial competence. If Thekiso's existing model, or parts of it, could be validated it could be operationalised as a model to measure managerial competence. Shaikh (2013) then applied Thekiso's model to another sample of the business school educated managers. This time the population was geographically located in KwaZulu-Natal and Gauteng provinces of South Africa.

Factors measuring managerial and leadership competence: The results obtained by Shaikh (2013) identified two factors explaining $37.83 \%$ of the variance. These factors were identified as Factor 1 (Managerial Skills) which explains $31.73 \%$ of the total variance. It also consisted of the majority of measuring criteria. Factor 2 (Ethical and External Influences) explained only $6.09 \%$ of the variance. This meant that Factor 1 was of much greater significance. However, closer scrutiny revealed that the first factor is generalized and that it may consist of sub-factors. In further analysis, Shaikh succeeded to identify a further seven sub-factors within Factor 1. The Shaikh model is shown in Figure 1.Improving on Thekiso's results, Shaikh succeeded to obtain satisfactory reliability of his factors (see Figure 1). Only the Sub-factor 7 showed a low reliability with its coefficient below the secondary margin of 0.57 (Cortina, 1993:101; Field, 2009). It is also evident that the more important factors (according to the variance explained), namely Factor 1 and its two main sub-factors ( 1 and 2 ) have high reliability coefficients that exceed 0.70 with ease. The other subfactors and Factor 2 also exceed the 0.57 secondary reliability margin with ease. The model is shown in Figure 1 where after each of the factors is discussed.

Factor 1-Skills for managerial competence: Sanchez and Heene (2004) state that competency-based theory is a relatively new way of thought about how organizations can improve and sustain high performance levels over time. This theory still holds as performance tool (Makulova et al., 2015:183; Takahashi et al., 2017). Established in the 1990s, competency-based strategic management theory explains how organizations can develop a sustainable competitive advantage in a systematic and structured way. The competency-based theory incorporates economic, organizational and behavioral concerns in a framework that is dynamic, systemic, cognitive and holistic. In the context of the present study, the term "competence" is viewed as the blend of knowledge, skills, abilities and behaviors needed to carry out tasks successfully. Managerial competence depends on both skills and knowledge based on understanding. Competence includes the capacity to transfer knowledge and skills to new tasks and situations. Here the Competing Values Framework (a framework of managerial competence developed by Evert, Lindquist and Macy (2014:182)) provides a foundation for developing managerial competencies and to guide managers to become "master managers". Here Kinghorn et al. (2015) expand the master manager concept, and state that the following eight roles are critical to becoming a master manager; that is to be a mentor, facilitator, monitor, coordinator, director, producer, broker and an innovator. On the other hand, Shaikh (2013) identified a subset of seven managerial skills that form the basis of his managerial competence model. These skills are discussed next. 
Figure 1: A theoretical model to measure skills for managerial competence

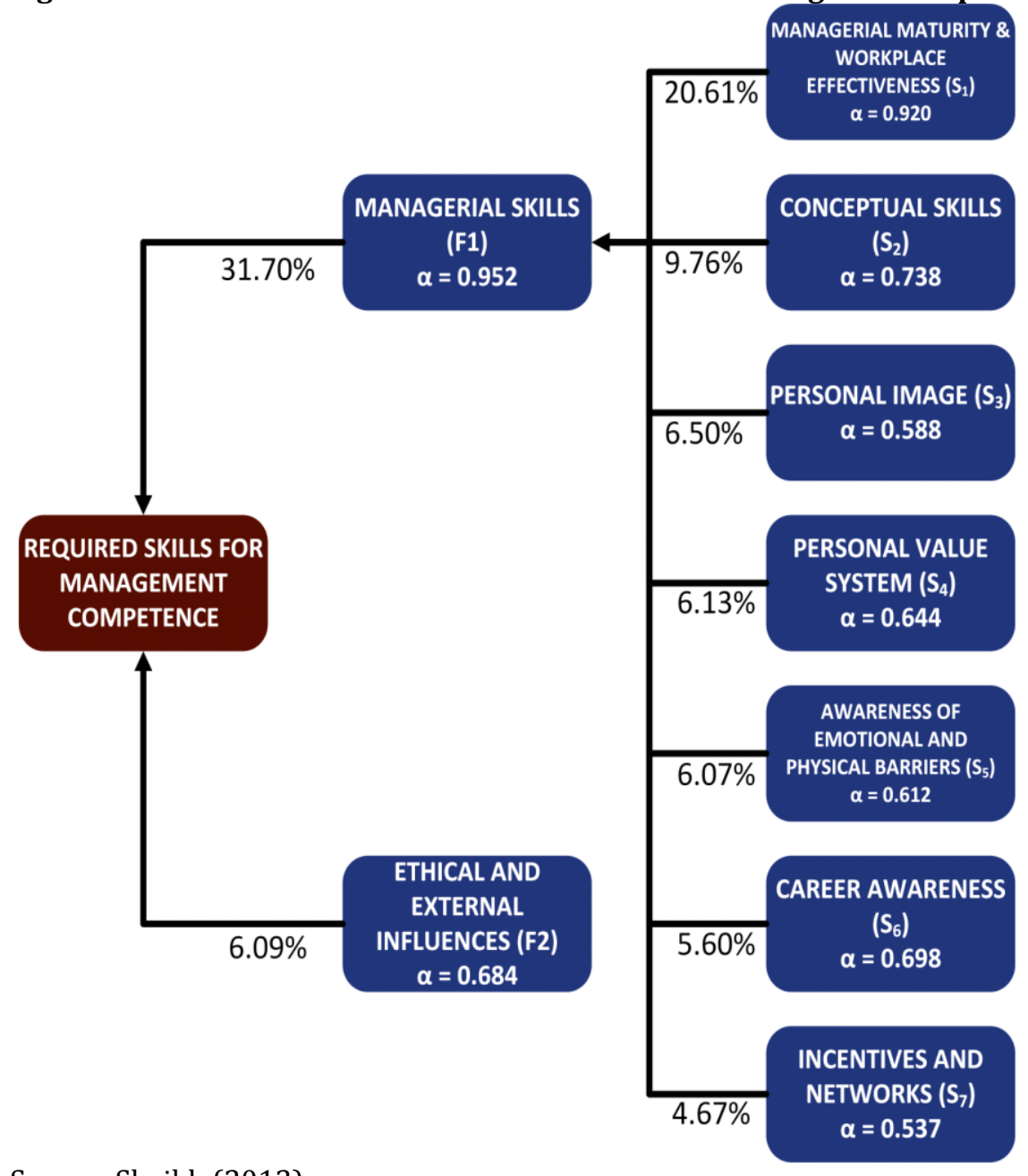

Source: Shaikh (2013)

Figure 1 shows that two factors could be identified, but that Factor 1 consists of seven sub-factors. These two factors and seven sub-factors are discussed below.

Sub-factor 1-Managerial maturity and workplace effectiveness: Given the complexity that accompanies managerial roles generally, managers often find themselves in an invidious position where they may be offended personally, where blame may be placed on them for matters outside of their sphere of influence, or they may become parochial and avoid taking uncomfortable actions. In such instances, the manager gets into the intricacies of being a mature leader as well as being able to overcome these obstacles in the workplace (Plachy, 2015). Here interviews by Thomas et al. (2014) with numerous founders of large United States companies offer an insight into their modest expectations at the time of company start-up and their genuine surprise at the size their firms did ultimately grow to. These interviews commonly identified that different managerial skills are needed to maintain success as the company grows, and that company growth presents a wide range of challenges for its leaders. The point at which growth will outstrip management ability is not easily predicted because the threshold is different for each leader and each management team. The leader must be able to identify when company growth is outpacing their managerial maturity. Changing existing management practices is extremely difficult for some leaders. A delegation of authority for a leader has two key benefits: first, it builds the company's managerial maturity, and second, it lessens the workload that is placed on the leader. 
Sub-factor 2-Conceptual skills: In his seminal study in 1955, Sydney Fine postulated the skills managers used and included the concept of conceptual skills (in Moore, 1999). Based on this work, research by Katz (1974:101) and the later works by Fine and Getake (2014:147), Wiley-Cordone (2016) attempted to define conceptual skills in management modernly as:

A skill that allows a manager to visualize the entire organization and work with ideas and the relationships between abstract concepts.

Katz's (1974:102) seminal study on the skills approach to leadership suggested that leadership is based on technical, human and conceptual skills. Additionally, Katz (1974:100) also points out that; top-level managers rely on and use conceptual skills strategic decision-making while lower level managers do so to supervise day-to-day operations. However, conceptual skills should be backed up by technical- and human skills to operationalize ideas and concepts in the workplace. Leaders with high levels of conceptual skills are good at thinking through the ideas that form an organization and its vision for the future, expressing these ideas in verbal and written forms and understanding and expressing the economic principles underlying their organization's effectiveness. These leaders are comfortable asking "what if" or other managerial based hypothetical questions and to work with abstract ideas. Here Northouse (2016) adds that conceptual skills allow leaders to give meaning to abstract ideas and to make sense of abstract ideas for their superiors, peers and subordinates.

In contrast to Katz (1974:101) and Wiley-Cordone (2016), Northouse (2016) state that conceptual skills are very important for top managers, less important for middle managers, and least important for supervisory managers. However, Yukl (2006) tends to disagree with Northouse's view (2016) and lean more towards the views held by Wiley-Cordone (2016) in this regard; that it is important to develop and demonstrate this skill at all levels of management. Even though conceptual skills are differently applied by the different levels of management, all need conceptual skills. Also, as managers get promoted to higher levels, early development of conceptual skills makes it easier for the manager to now operate on the higher level after the promotion. The modern economy also requires conceptual skills. Here a study by Abbatiello et al. (2017) points out that digital leadership is most relevant and that managers do need conceptual skills in the modern digitalized economy to make astute management decisions. These authors, in a collaborative study with the Business School at the Massachusetts Institute of Technology, concluded that for leadership capabilities to succeed in a digital world it must include conceptualizing possibilities in a virtual world, handling ever-increasing cognitive complexity, thinking divergently about new ways of doing things and making decisions quickly without all of the information.

Sub-factor 3-Personal image: The modern marketplace and competitive environment are strongly social media-based and increasingly driven by the value-proposition offered by organizations to its customers (Halzack, 2016). To a large extent, competitive disruption has shifted from the technological sphere to social and personal spheres of peoples' lives. Driven by a pervasive social media phenomenon, the personal image of leaders is often referred to as having a personal brand (Llopis, 2013). This personal brand is also transferred to the managerial position; hence the personal life and the employ become inter-connected on social media. A typical example in the South African political economy is when a prominent foreign business family (based in South Africa) was accused of being involved in large-scale corruption, they employed "spindoctors" to improve and craft their personal image as wealthy businessmen committed to supporting Black Economic Empowerment in South Africa (Shaikh, Karodia and Soni, 2017:20). This example underscores, albeit negatively, how leaders may use their personal image to influence and gain favor among stakeholders in business and society.

Sub-factor 4-Personal value systems: Katulwa (2015:197) notes that "Leaders carry out this process by applying their leadership attributes such as beliefs, values, ethics, character, knowledge and skills". Though attributes are more difficult to develop than leadership behaviors (Tubbs \& Schulz, 2006:497), management and leadership development efforts should focus on building a solid character as the foundation stone upon which to develop leadership behaviors. Some ethical lapses and corporate scandals are typical expressions of character flaws in the lives of senior business leaders (Katulwa, 2016). Here Volkswagen's Dieselgate, Sepp Blatter, the disgraced former head of soccer's international governing body, and Martin Shkreli the CEO of the drug company Turing who increased the price of an HIV drug by 5,000\%, serve as examples where personal 
values failed executives (Mathews \& Gandall, 2015). Here Dillon and Bourke (2016) state that inclusive leaders should also align their personal values towards inclusion by treating all team members with fairness and respect, understanding the uniqueness of each team member, taking action to ensure each team member feels connected to the group/organization and proactively adapt their work practices to meet the needs of others.

Sub-factor 5-Awareness of emotional and physical barriers: This sub-factor deals with managerial barriers, more so the emotional and physical barriers managers' experience. Scrutiny of the literature provides very limited support for this factor, especially the model deals with managerial competencies and not with managerial barriers. Consultation of the original documentation where the model was developed, however, revealed that although the sub-factor seems not to befit the model, Shaikh has reported on it for completeness sake. The specific factor showed little promise hence it is omitted from the model. The individual criteria which loaded onto the sub-factor were retained though because they might add value (or not) in further model evaluation and development. If not, these criteria were deleted from the list.

Sub-factor 6-Career awareness: Carr (2008) seminally questioned the advancements in the digital age and its effect on human intelligence and detailed the fundamental shift in learning, reading and memorization that has taken place in recent years as a result of the digital proliferation. Additionally, he pointed out that "there are simply not enough highly specialized technical workers available for existing vacancies and needs". Nanterme (2016), in support, recognized this gap and indicated that the digital revolution is the main reason that more than $50 \%$ of the Fortune 500 companies have disappeared since the year 2000 . This heeds a stern warning to career competence and keeping ones' career relevant to deal with challenges in a changing environment. Constant training, development and retraining are required to remain relevant and competitive in a career. Hence lifelong learning and a self-motivated pursuit of knowledge are defining features of the new knowledge economy. Changes brought by the Fourth Industrial Revolution are widening the global talent shortage; a gap that will only worsen as advances in technology further increase existing talent mismatches. Evidence from Accenture's research (2016) shows those technical jobs (at all the skills levels) require more than pure technical skills.

Sub-factor 7-Incentives and networks: Giles (2016) based on feedback from influential leaders worldwide, state that the most important leadership competency is to foster a strong sense of connection and belongingness. Her study also indicates that this sense of connection and belongingness is achieved by leaders who communicate often and openly, and create a team experience when achieving success or experience failure. Historical leader behavior, such as "heroship", is outdated. Here research by Abatiello et al. (2017) highlights that companies such as Google, Lyft, WL Gore, Mastercard, and Atlassian focus on team leadership and they recruit leaders who can work together as a team, complement one another, and function as a team. Abatiello et al. (2017) go on to argue that when older business models are no longer working, leaders need new competencies to redesign their organizations to be more dynamic, team-centric, and connected.

Factor 2-Ethical and external influences: Ethical responsibility is an increasingly key factor in determining a leader's success. Whetten and Cameron (2015:37) state that today's public has high standards for the behaviors of companies. Laws and lawsuits more frequently follow violations of formalized ethical standards, and competitors are quick to market how they are more ethical than other companies. Also, the behavior of managers is under greater scrutiny than ever before. Because the public has easier access to information, misdeed can almost instantly become widely known, damaging an organization's reputation and a manager's career. A survey conducted by Sulaiman and Mohezar (2009) on the students 'perception of the quality of MBA programs' established the need for MBA programs to consider ways of improving ethical awareness among MBA graduates. Leaders in businesses and other organizations are daily faced with ethical issues such as conflict of interest, communication, lack of fairness and equity in rendering services, opportunities to offer or accept bribery and kickbacks among many others. Leaders, therefore, need to be acquainted with the basic knowledge of ethical language and implications of their choices before they can be preferred to deal with temptations that come with leadership positions that they hold. Here Bisschoff (2017) performs longitudinal research spanning over nine countries and six continents to measure and compare ethical attitudes of MBA students. According to research by Giles (2016), leaders who demonstrate strong ethics and provide a sense 
of safety are among the most highly rated attributes of the ten most important attributes of 195 leaders from 30 global organizations. Giles summarizes by stating that leaders with high ethical standards convey a commitment to fairness, and instilling confidence that both they and their employees will honor the rules of the game. In a safe environment, the employees can relax, invoking the brain's higher capacity for social engagement, innovation, creativity, and ambition.

Shortcomings of the model: The abovementioned model holds three significant shortcomings, namely that of recency, variance explained and an unsupported factor from theories studied in the literature.

- The model by Shaikh (2013) was developed from the theoretical framework by Thekiso (2011). This means that the fast-developing technological environment and the Fourth Industrial Revolution are not fully incorporated in the model. Also, human aspects such as constant career development, burnout and stress and emotional challenges in the work environment are not part of the original model variables. The model thus has to "modernize" to befit the new economic and technological environment managers operate in.

- The model results show a relatively low variance explained. The analysis identified two main factors explaining a cumulative variance of $37.83 \%$ (thus not achieving the desired $60 \%$ variance explained). This means that the model does consider the majority of the managerial competencies and that there are other managerial skills that can be gleaned from literature to improve the managerial competencies. In practice, this means that it is required to identify relevant managerial competencies further to add to the current model.

- One variable identified by the Shaikh model (Awareness of emotional and physical barriers) seems to be population specific as there is no supporting evidence from any of the theories studied in the literature. Lack of evidence from an extensive literature review suggests that this variable is not general and has therefore been discarded from the model.

Adapted literature constructs of the model: The model developed by Shaikh (2013) has a broad literature base. These supporting sources are listed in Table 1.

Table 1: Constructs from the original model

\begin{tabular}{ll}
\hline Constructs & Sources of Support \\
\hline $\begin{array}{l}\text { Managerial maturity } \\
\text { workplace effectiveness } \\
\text { Conceptual skills }\end{array}$ & Plachy (2015); Thomas et al. (2014) \\
& Katz (1974); Yukl (2006); Northouse (2016); Wiley-Cordone (2016); \\
Personal image & Abatiello et al. (2017) \\
Personal value systems & Llopis (2013); (Halzack, 2016); Shaikh et al. (2017) \\
& Hernez-Broome \&Hughes (2004); Tubbs \&Schulz (2006); Satija \\
& (2009); Berger et al. (2012); Katulwa (2015); Katulwa (2016); Dillon \\
and Bourke (2016) & Carr (2008); Hogan \&Hogan (2001); Nanterme (2016); Accenture \\
& (2016) \\
Incentives and Networks & Giles (2016); Abatiello et al. (2017) \\
Ethical and External Influences & Sulaiman and Mohezar (2006; 2009); Whetten \&Cameron (2015:37); \\
& Giles (2016); Bisschoff (2017) \\
\hline
\end{tabular}

Given the successes, the shortcomings and strong literature base of the current model, it seems worthwhile to attempt improvement of the model and expanding it to increase the variance explained by the managerial competencies. To do the model needs to expand the literature base, add more skills and also add more measuring criteria to peruse and analyze.

Expanding the Model: The literature study reveals that the following managerial and leadership competencies should be considered in addition to the ones already identified by both Shaikh (2013) and Thekiso (2011).

Emotional Intelligence: The most effective leaders are all alike in one crucial way: they all have a high degree of what has come to be known as emotional intelligence. This view does not purport to suggest that 
the Intelligent quotient (IQ) and technical skills are irrelevant. While these skills do matter; they are the entry-level requirements for executive positions (Cherniss et al., 1998 cited in Ovans 2015). Emotional intelligence, as a theory of performance, reflects how an individual's potential to master the skills of selfawareness, self-management, social awareness, and relationship management translates into on-the-job success. Goleman's pioneering research, along with other recent studies (Abbatiello et al., 2017; Ovans, 2015; Stein, 2017), clearly shows that emotional intelligence is not a new skill that is 'sine qua non' for leadership, but that it is needed now more than ever before. Without it, a person can have superior training, an incisive, analytical mind, and an endless supply of smart ideas, but this would not ensure great leadership (Cherniss et al., 1998). In the context of the modern digital economy, Abbatiello et al. (2017) argue that leadership is regarded as critical in transforming an organization "doing digital things" to one that is "becoming" digital. For both the organization and its leaders, this involves three different types of transformations

- Cognitive transformation: Leaders need to think differently;

- Behavioral transformation: Leaders need to act differently; and

- Emotional transformation: Leaders need to react differently.

According to Stein (2017), leadership research on emotional competencies is still in transition. This means that while many of the 'hierarchical and authoritarian' styles of leadership have become obsolete, and 'transactional' management styles have proven unproductive, new studies have encouraged the embrace of 'transformative styles' in which organizational leaders inspire their teams to achieve a collective purpose. Stein (2017) goes on to suggest that more leaders need to be equipped with the skills that combine interpersonal abilities, including empathy and trust, with the capacity to model creative problem solving when faced with tough situations. The managerial skill referred to as emotional competence has been identified by Goleman (and other EI theorists) as part of the skills set high-performing managers possess; a skill that will be more in demand in the Fourth Industrial Revolution.

Leading change: The customary, rather rigid corporate structures do not allow for agile change between the various leadership roles. Hoffmann (2016:12) indicates in this regard that, in the context of the Fourth Industrial Revolution, the multiple hierarchical levels in the conventional organizational model will become obsolete and eventually disappear. The typical silo-mentality associated with the hierarchical organizational design will fade, and this should unlock innovation in organizations that will, in addition to exploiting the current business environment, also allow leaders to incorporate experimentation of new ideas, innovate and to achieve a balance to secure long-term success. Here Truxillo, Bauer and Erdogan (2016:12) confirm that the organization has to learn continuously without any boundaries and adjusted organizational structures if necessary.

A defining feature of the Fourth Industrial Revolution is the digital change that comes along with it; digitalization requires constant strategic review and mission adaptation (Anderson, 2017). Here Eulitz (2016:13) adds that a leading proponent of the digital change phenomenon is that digitization has to be anchored deeply in the organization as an essential success factor for business growth. In this regard, companies are hiring Chief Digital Officers who lead interdisciplinary teams with special skills in the field of digitization, for example, e-commerce, and function as a start-up within an existing company (Eulitz, 2016:13). Sign (2016:14) highlights that, in contrast to a conventional executive, contemporary leaders are characterized by their openness to embrace change and innovation: He argues that although the traditional meaning of leadership should not change much, the concept of innovation management will. The question of managerial adaptability, ability to change and the recognition of opportunities and threats in a digitized fastmoving business environment surfaces as future managerial and leadership challenges.

Cultural intelligence: In the 21st century, cultural sensitivity and competence have been widely recognized as a critical factor to the success of the leadership process and organizational transformation (Sulaiman \& Mohezar, 2006). Increased globalization has amplified cultural diversity in the workplace has made the ability to lead across cultures a critical managerial competence for effective managers. With increased advances in communication and technological convergence, the degree of cultural diversity is bound to increase, and that will continue to exert pressure upon organizational leaders to enhance their capacity to connect in nontechnical ways (Dunwood \& Peters, 2016). Hitt, Black and Porter (2005:115) define culture as "A learnt set of assumptions, values, and behaviors that have been accepted as successful enough to be passed to 
newcomers". The relevance of culture to business leadership lies in its impact on behavior. Consequently, business leaders with cultural understanding and sensitivity are better placed to leverage culture and use it to help accomplish organizational goals. The business leader of the 21st century is more likely to work with a more culturally diverse workforce than their predecessors of the 20th century. Walker et al. (2003:23) describe the knowledge-based economy as the era of global business where a "different level of awareness, competence and skill is required to navigate the relativity and complexity of the multicultural global work and marketplace". Further, they identify five interrelated aspects of cultural competence that they argue could be developed through continuous learning and development. These learnable interrelated aspects of cultural competence include; open attitude, self-awareness, other awareness, cultural knowledge and, crosscultural skills (Walker et al., 2003; Fong et al., 2016); leadership and managerial competencies required in a fast-changing business environment.

Teambuilding: At the start of the century, MacMillan (2001) already depicted the $21^{\text {st }}$ century business as a team-sport environment where new rules apply, and world-class competition is the order of the day. To succeed in this environment, businesses need to function like high-performance teams characterized by clear, common purpose, crystal clear roles, accepted leadership, effective team processes, solid relationships and, excellent communication. Campbell (2006) later further explored the concept of teams and identified three critical reasons for developing teambuilding competency among business leaders in the knowledge economy:

- Team performance is a major determinant of the overall organizational performance;

- Business leaders of the 21st century is going to spend a greater portion of their time working in teams; and

- Business leaders wishing to maximize their personal potential should develop their team leadership skills on a smaller scale before they can advance to leading multiple teams.

Here Maitland and Anderson-Terry (2017) confirm the importance of teams in business to cope with the disruptive changes the Fourth Industrial Revolution brings about. This is specifically relevant to South African managers and leaders because $68 \%$ do not understand the influence these disruptive changes have on managers while in $44 \%$ of South African organizations, the workforce strategy is not aligned with the innovation strategy (Hattingh, 2016). Hattingh also points out that virtual teams and its management is also a required competence in the postmodern business environment.

Strategic leadership: Strategic leadership has been identified as a source of competitive advantage (Day et al., 2009:14). Hitt, Ireland and Hoskisson (2012:63) defined strategic leaders regarding the manager's "ability to anticipate, envision, maintain flexibility, think strategically, and work with others to initiate changes that will create a viable future for the organization". Looked at it from that perspective, strategic leadership bears within it the potential to create a competitive advantage for an organization to the extent to which it is hard to be imitated by competitors. To function effectively in an interdependent, increasingly complex, and dynamic knowledge-based economy of the 21st century, managers and leaders need to enhance strategic leadership skills more than ever before (Hattingh, 2017). A point stressed by Anderson (2017) who indicates that the continued acceleration of innovation and the velocity of disruption demand that management strategy is continuously adjusted to remain competitive. Here Swartz and Potgieter (2017) point out that this accelerated change will increase stress; hence managers should be skilled in dealing with stress in the modern economy.

Conflict management: Conflict may be described as a struggle between at least two parties arising from incompatible goals, competition for scarce resources, different perception of given a situation or, perceived interference from the other party in achieving their goals (Campbell, 2006). In the knowledge economy of the 21st century, conflicts are a prominent feature in the workplace and require people skills, self-management skills, and also leading skills (Anon., 2017).Reese (2016), however, state that the manager or leader should be conscious of their ability, or lack thereof to manage conflict. He cites Maslow's views in this regard who categorized managers or leaders conflict competencies as:

- Unconscious incompetence: Here managers who are incompetent in one (or more) of the conflict management skills, doesn't know that they are incompetent; they blame others for their incompetence. 
- Conscious Incompetence: These managers are incompetent in an (or more) conflict management skill(s), and they know it. They are aware that they need to learn these skills.

- Conscious Competence: These managers have learned specific conflict management skill(s) which they apply skill consciously.

- Unconscious Competence: These managers have conflict resolving skills, and they apply the skill consistently but "as part of their management skills", not as a conflict resolution skill.

- Here Reese (2016) points out that business leaders and managers should establish good communication links to be good at managing conflict.

Communication skills: Leadership is about influencing others to achieve agreed desired goals, and this is done through communication. Communication skills competence has been (Certo, 2000; Conrad \& Newberry, 2011; Du Babcock, 2006) and still is widely regarded as a critical determinant of organizational success (Reese, 2016; Anon., 2017). Wiemann (1977) described communication skills regarding the ability to choose between different available communicative behaviors, in a way that successfully fulfils the users' interpersonal goals. Several studies have underscored the need for business education to include development of communication skills in the curriculum in order to address the apparent gap between the graduates' skills level and what is desired by the business industry (Lanier et al., 1997; Tanyel, Mitchell \& McAlum, 1999; Roebuck, 2001; Kamal, 2015). Here Kamal (2015) points out that nine communication skills are required by managers, namely active listening skills, writing skills, verbal skills, interpersonal communication skills, teamwork skills, presentation skills, selling skills, negotiation skills and networking skills. Considering that, a leader's performance is closely tied to his/her communication competence (Frederickson, 2006) and that most leaders will spend close to $40 \%$ of their time communicating with their constituents (Simpson, 2006), communication is a core competency; managers should master. Giles (2016) also lists communication as key skill managers should possess. Generally, management researchers agree that both oral and written communication skills are key in communication competence (Reese, 2016; Giles, 2016; Anon., 2017).

Global leadership mindset- Rogers and Bloski, 2010:19) describe a global mindset as:

The capacity to engage in a boundaryless and synthesizing cognitive process that identifies opportunity and innovation in complexity.

Two modern definitions of the global mindset in business are offered by IGIGlobal (2017) as:

A meta-capability that permits an individual to function in the new and unknown situation and to integrate this new understanding with other existing skills and knowledge.

and

Managerial openness to and awareness of diversity across cultures and markets with an ability to see and seize the global opportunities, to adopt sustainable and ethical good managerial practices wherever they come from, cooperating globally to the benefit of all stakeholders accepting the philosophy of integrity in their actions.

Encompassed within the global mindset is the ability to see beyond national culture, organizational boundaries, corporate gain and functional responsibilities to the society as a whole. The global leadership mindset is essential for success in the $21^{\text {st }}$ century because it enables leaders to embrace paradox and complexity which are indispensable skills in a dynamic first changing environment (Rogers \& Blonski, 2010:2). Studies have recommended a multi-dimensional approach where the global mindset allows managers to expand beyond their limits of their existing behavior and incorporate ethnocentric thinking, diversity and differences in their management activities to function effectively on a global platform (Cohen, 2010; IGI Global, 2017).

\section{Expanded Theoretical Model to Measure Managerial Competence}

The managerial competencies identified by the original models and the extended literature study are combined in a new theoretical model to measure managerial competence. The relevant new competencies and their supporting theory are summarized in Table 2 . The table includes the original competencies by Thekiso (as adopted and adapted by Shaikh) and also the newly added competencies from the literature study. However, overlapping competencies and skills resulted that from a possible sixteen competencies, a total of eleven core managerial and leadership competencies were identified. These competencies appear in 
the table below. The relevant measuring criteria based on the theory to measure each of the competencies also appear in this table.

Table 2: Additional constructs supported by the literature

\begin{tabular}{|c|c|c|}
\hline $\begin{array}{l}\text { Global } \\
\text { Leadership } \\
\text { Competence }\end{array}$ & Measuring criteria & Origin \\
\hline Leading change & $\begin{array}{l}\text { As a leader, I need to be prepared to help my organization } \\
\text { to keep pace with change } \\
\text { I believe that there is a relatively high level of failure in } \\
\text { strategic change efforts in organizations } \\
\text { As a leader, I need to drive the topic of change, be a change } \\
\text { agent myself and promote diversity } \\
\text { MBA programs must include a course on managing } \\
\text { strategic change in the core curriculum } \\
\text { I believe that most managers do not embrace the reality of } \\
\text { regular change in their organizations }\end{array}$ & $\begin{array}{lr}\text { Hoffmann } & (2016) ; \\
\text { Truxillo et al. } & (2016) ; \\
\text { Eulitz } & \text { (2016); Sinh } \\
(2016) ; & \text { Anderson } \\
(2017) & \end{array}$ \\
\hline $\begin{array}{l}\text { Cultural } \\
\text { intelligence }\end{array}$ & $\begin{array}{l}\text { I believe that cultural intelligence is a critical success factor } \\
\text { of the leadership process and organizational } \\
\text { transformation } \\
\text { Leaders with cultural understanding and sensitivity are } \\
\text { better placed to leverage culture and use it to help } \\
\text { accomplish organizational goals } \\
\text { Increased advances in ICT, the degree of cultural diversity } \\
\text { is bound to increase pressure on organizational leaders }\end{array}$ & $\begin{array}{l}\text { Chin and Gaynier } \\
\text { (2006); Sulaiman and } \\
\text { Mohezar (2006); Walker } \\
\text { et al. (2003); Hitt et a. } \\
\text { (2005); Hitt et al. } \\
\text { (2012); Fong (2016) }\end{array}$ \\
\hline Team building & $\begin{array}{l}\text { Team performance is a major determinant of the overall } \\
\text { organizational performance } \\
\text { Business leaders of the } 21 \text { st century is going to spend a } \\
\text { greater portion of their time working in teams } \\
\text { I believe that leaders who are collaborative are most } \\
\text { successful in their leadership efforts } \\
\text { Collaborative leaders generate goodwill in the team, which } \\
\text { in turn enhances team performance }\end{array}$ & $\begin{array}{l}\text { MacMillan (2001); } \\
\text { Campbell (2006); } \\
\text { Hattingh (2016); Reese } \\
\text { (2016); Maitland } \\
\text { \&Anderson-Terry } \\
\text { (2017), }\end{array}$ \\
\hline $\begin{array}{l}\text { Strategic } \\
\text { leadership }\end{array}$ & $\begin{array}{l}\text { Strategic leadership focuses less on day-to-day events and } \\
\text { more on underlying trends and patterns } \\
\text { Strategic leadership has the potential to create a } \\
\text { competitive advantage for an organization which is hard } \\
\text { for competitors to imitate } \\
\text { Strategic leaders envision the future and inspire others to } \\
\text { work towards creating a viable future for the organization } \\
\text { Strategic leadership is directly connected to organizational } \\
\text { renewal and strategic innovation }\end{array}$ & $\begin{array}{l}\text { Day (2000); Oritz } \\
\text { (2004); Hitt et al. } \\
\text { (2012); Anderson } \\
\text { (2017); Hattingh (2017) }\end{array}$ \\
\hline $\begin{array}{l}\text { Conflict } \\
\text { management }\end{array}$ & $\begin{array}{l}\text { I must manage the gaps and tensions that emerge due to } \\
\text { the diversity of my team members } \\
\text { A leader's conflict management ability is key to the current } \\
\text { business environment of diversity, complexity and } \\
\text { continuous change. } \\
\text { If I manage conflict poorly, business performance will } \\
\text { suffer }\end{array}$ & $\begin{array}{l}\text { Campbell (2006); Kamal } \\
\text { (2015); Reese (2016); } \\
\text { Anon. (2017) }\end{array}$ \\
\hline $\begin{array}{l}\text { Communication } \\
\text { skills }\end{array}$ & $\begin{array}{l}\text { A leader's performance is closely tied to his/ her } \\
\text { communication competence } \\
\text { MBA degrees and business education programs must } \\
\text { include communication skills to improve graduates' impact } \\
\text { in the workplace. } \\
\text { Leaders spend a substantial part of their time }\end{array}$ & $\begin{array}{l}\text { Dilenscneider (1992); } \\
\text { Wiemann (1997); } \\
\text { Lannier, Tanner, Zhu } \\
\text { and Heady (1997); } \\
\text { Tanyel et al. (1999); } \\
\text { Fredrickson (2006); Du- }\end{array}$ \\
\hline
\end{tabular}


communicating with their constituents.

Influencing others is central to leadership, and this is achieved through effective communication.

Communication will increasingly become networked and matrix-based across multidisciplinary teams

I understand the global mindset is the ability to see beyond national culture, organizational boundaries, and local Global leadership mindset

Emotional Intelligence

Ethical and
External
influences

Career awareness

Personal value system business opportunities.

The global leadership mindset is essential for success in the 21st century because it enables leaders to embrace paradox and complexity

I understand self-awareness to be a key part of emotional intelligence

Emotional intelligence can result in an outstanding performance at work. An emotionally intelligent leader is aware of relationship management as well as task orientation

An emotionally intelligent leader is aware of relationship management as well as task orientation.

If I am emotionally intelligent, I understand the impact that my emotions and behavior would have on others around me.

The public has higher expectations these days for the ethical behavior of companies

MBA graduates are required to reflect greater ethical awareness - especially since the 2008 crisis

Leaders in business are regularly faced with ethical issues others

Leaders must have a basic knowledge of ethical language and behaviors in their daily interactions

I am aware that employees are required to have technical skills in the digital economy

Lifelong learning is an essential feature of career development in the knowledge economy

Career planning is part of my self-development - rather than my employer's responsibility

I am aware that even technical jobs require soft skills such as creativity, collaboration and business savvy

I apply my own beliefs, values, ethics, knowledge and skills in my leadership style

Leadership behaviors are to be built on character as a

foundation

Ethical lapses in business are partly a result of character

flaws of leaders

The demonstration of solid character is going to be an indispensable quality of $21^{\text {st }}$ century leaders such as bribery, corruption, kickbacks for contracts among
Babcock (2006); Certo (2000); Simpson (2006); Conrad and Newbury (2011); Giles (2016); Reese (2016); Anon. (2017)

Rogers and Blonski (2010); Cohen (2010); IGIGlobal (2017)

Cherniss et al. (1998); Ovans (2015); Boyatzis, Goleman and Rhee (2000); Abatiello et al., (2017); Stein (2017)

Sulaiman and Mohezar (2006; 2009); Whetten \&Cameron (2015:37); Giles (2016); Bisschoff (2017)

Carr (2008); Hogan \&Hogan (2001); Nanterme (2016); Accenture (2016)

Hernez-Broome \&Hughes (2004); Tubbs \&Schulz (2006); Satija (2009); Berger et al. (2012); Katulwa (2015); Katulwa (2016); Dillon and Bourke (2016)

Table 2 is a summary table of the literature study on the managerial and leadership competencies. The table shows how each competency can be measured and where the specific measuring criteria originated from in the literature. Also, some criteria were also drafted from lines of thought of multiple studies, and could not specifically attribute to a specific study; these criteria were compiled and listed based on the general literature. This table serves as the empirical structure of measuring instrument, a questionnaire, that will be 
used to measure managerial and leadership competence among South African business leaders. The adapted model to measure managerial and leadership competence appears in Figure 2.

Figure 2: The adapted model to measure managerial and leadership competence

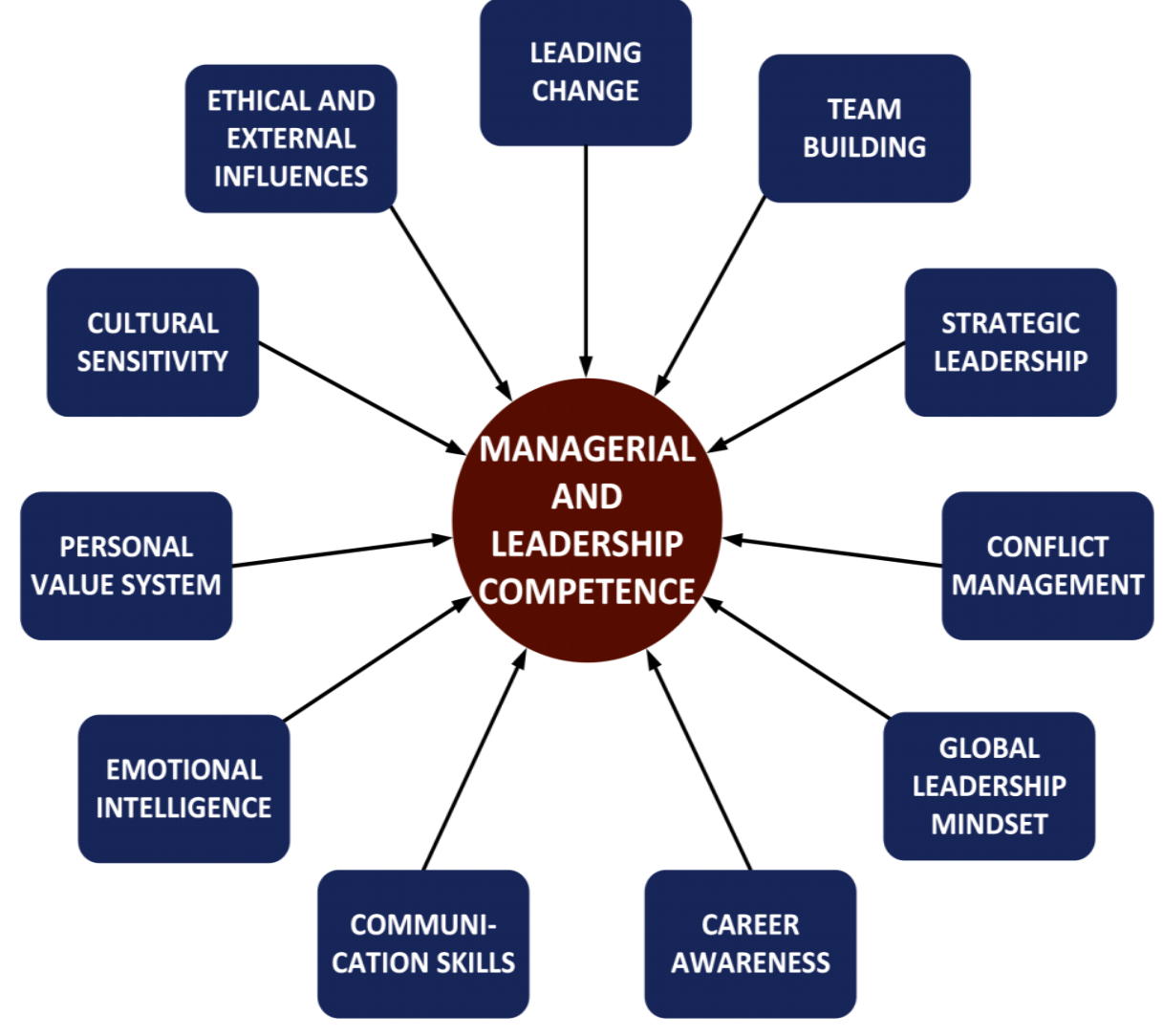

The identified eleven managerial competencies are shown in the figure. These competencies represent the theoretical model, and further research needs to be done to substantiate these competencies as valid measures of managerial competence.

\section{Conclusion}

This article started with an existing theoretical model to measure managerial and leadership competencies of business school educated managers. The model presented by Shaikh (2013) was an adapted theoretical based on a conceptual model originally presented by Thekiso (2011). While the Shaikh model reflected a fundamentally different factor and sub-factor structure to the conceptual model by Thekiso (2011), it succeeded to progress in the right direction by overcoming failures experienced by Thekiso. However, the key shortcoming is the variance explained that falls dismally short of the desired $60 \%$. At the current $37 \%$ of the variance explained, it means that $63 \%$ of the variance is not explained; this is unsatisfactory. This meant that the model had to be extended and 'modernized' to reflect the latest dynamics and factors of managerial and leadership competencies related to the current dynamic and complex global business environment. In extending the current model to measure managerial competence more comprehensively, seven competencies were retained from the existing Shaikh model. One competency was discarded because it showed a lack of supportive evidence for the theory. Also, and based on an extensive literature review, another nine competencies were added from an extensive literature study. These new competencies sought to accommodate the key elements of managerial and leadership skills that were missing from the original theoretical model by Shaikh (2013). Although there are 16 skills in total, the new set of competencies embeds some of the original competencies. This means the model now has eleven managerial competencies to measure, each with its unique set of measuring criteria. 


\section{References}

Abbatiello, A., Knight, M., Philpot, S. \& Roy, I. (2017). Leadership disrupted: Pushing the boundaries. Global human capital trends. London: Deloitte University Press.

Accenture Research. (2017). The future has arrived. https://www.accenture.com/us-en/blogs/blogs-futurework-arrivedDate of access: 10 September 2017.

Anderson, L. (2017). 11 Leadership guidelines for the digital age. https://knowledge.insead.edu/leadershiporganisations/11-leadership-guidelines-for-the-digital-age-5516\#5iYzCEH60ZF095kY.99 Date of access: 10 May 2017.

Anon (2017). 28 Leadership core https: //www.fsa.usda.gov/Internet/FSA_File/leadership_core_competencies.pdf Date of access: 10 May 2017.

Berger, E., Painter, M., Carrasco, R. L. \& Madala, L. (2012). Leadership by design: An architecture to build leadership in organizations. London: Deloitte University.

Bisschoff, C. A. (2017). A longitudinal view of the attitudes on business ethics of South African managers: trends from 2007 to 2016. Journal of Humanities, In press.

Botes, Z. (2014). Investigating the role of managers in enhancing performance culture. (Dissertation - MBA). Potchefstroom: NWU.

Boyatzis, R. E., Goleman, D. \& Rhee, K. (2000). Clustering competence in emotional intelligence: Insights from the Emotional Competence Inventory (ECI). Handbook of Emotional Intelligence, 99(6), 343-362.

Brynjolfssen, E. \& McAfee, A. (2014). The Second Machine Age: Work, progress, and prosperity in a time of brilliant technologies. New York, NY: WW Norton.

Campbell, N. M. (2006). Correctional leadership competencies for the 21st century: Manager and supervisor levels. (National Institute of Corrections, U.S. Department of Justice. No. NIC Accession Number 020475).

Carr, N. (2008). Is Google making us stupid? What the Internet is doing to our brains". July/ August 2008. http://www.theatlantic.com/magazine/archive/2008/07/is-google-making-us-stupid/306868/ Date of access: 12 May 2017.

Certo, S. (2000). Modern management: Diversity, quality, ethics and the global environment. Upper Saddle River, NJ: Prentice-Hall.

Cherniss, C., Goleman, D., Emmerling, R., Cowan, K. \& Adler, M. (1998). Bringing emotional intelligence to the workplace: A technical report issued by the consortium for research on emotional intelligence in organizations. http://www.eiconsortium.org/research/technical_report.htm Date of access: 12 May 2017.

Cohen, S. L. (2010). Effective global leadership requires a global mindset. Industrial and Commercial Training, 42(1), 3-10.

Conrad, D. \& Newberry, R. (2011). 24 business communication skills: Attitudes of human resource managers versus business educators. American Communication Journal, 13(1), 4-22, Spring.

Cortina, J. M. (1993). What is coefficient alpha? An examination of theory and applications. Journal of Applied Psychology, 78(1), 98-104.

Cumberland, D. M. \& Alagaraja, A. (2016). Assessment and development of global leadership competencies in the workplace: A review of the literature. Advances in Developing Human Resources.http://journals.sagepub.com/doi/pdf/10.1177/1523422316645883 Date of access: 10 May 2017.

Daft, R. L. \& Marcic, D. (2016). Understanding management. Scarborough: Nelson Education.

Day, D. V., Harrison, M. M. \& Halpin, S. M. (2009). Educating for a peaceful world. American Psychologist, 48(5), 510-517.

Dillon, B. \& Bourke, J. (2016). The six signatures traits of inclusive leadership. London: Deloitte University Press.

Du-Babcock, B. (2006). Teaching business communication: Past, present, and future. Journal of Business Communication, 43(3), 253-264.

Dunwoody, S. \& Peters, H. P. (2016). Mass media coverage of technological and environmental risks: A survey of research in the United States and Germany. Public understanding of Science, 25(8):893-908.

Eulitz, C. (2016). The digitization megatrend. https://www.strategyand.pwc.com/global/home/what-wethink/digitization/megatrend Date of access: 12 May 2017. 
Field, A. P. (2009). Discovering statistics using SPSS. $3^{\text {rd }}$ ed. London: Sage.

Fine, S. \& Getake, S. F. (2014). Benchmark tasks for job analysis: A guide to functional job analysis. London: Psychology Press.

Fong, E. H., Catagnus, R. M., Brodhead, M. T., Quigley, S. \& Field, S. (2016). Developing the cultural awareness skills of behavior analysts. Behavior Analysis in Practice, 9(1), 84-94, March.

Frederickson, P. J. (2006). Political skill at work. Academy Management Perspectives, 20(2), 95-96.

Giles, S. (2016). The most important leadership competencies according to leaders around the world. https://hbr.org/2016/03/the-most-important-leadership-competencies-according-to-leadersaround-the-world Date of access: 12 May 2017.

Goleman, D. (1997). Emotional intelligence. New York, NY: Bantam.

Hatting, S. (2016). Skills planning for the disruptive Fourth Industrial Revolutionhttp://www.usbed.com/WatchReadListen/Pages/Skills-planning-for-the-disruptive-Fourth-IndustrialRevolution.aspx\#xR3cjHOBiZVBww4Q.99 Date of access: 15 August 2017.

Halzack, S. (2016). Social media 'influencers': A marketing experiment grows into a mini-economy. The Washington Post. https://www.washingtonpost.com/business/economy/social-media-influencersa-marketing-experiment-thats-metastasized-into-a-mini-economy/2016/11/02/ bf14e23a-9c5d11e6-9980-50913d68eacb_story.html?utm_term=.681d2d900b9e Date of access: 12 May 2017.

Hernez-Broome, G. \& Hughes, R.L. (2004). Leadership development: Past, present, and future. People and Strategy, 27(1), 21-24.

Hitt, M. A., Black, J. S. \& Porter, L. W. (2005). Management. Upper Saddle River, NJ: Prentice-Hall.

Hitt, M. A., Ireland, R. D. \& Hoskisson, R. E. (2012). Strategic management cases: competitiveness and globalization. London: Cengage Learning.

Hoffman, R. (2016). Interview: PayPal and LinkedIn. Boston, MA: Harvard Business review.

Hogan, R. \& Hogan, J. (2001). Assessing leadership: A view of the dark side. International Journal of Selection and Assessment, 9, 40-51.

IGIGlobal. (2017). What is global mindset? https://www.igi-global.com/dictionary/global-mindset/12243 Date of access: 12 May 2017.

Kamal, P. (2015). Importance of communication skills for students. https://www.linkedin.com/pulse/importance-communication-skills-students-communication Date of access: 10 May 2017.

Katulwa, B. (2015). Assessing the Perceived Level of Integration of Leadership Values and Ethics within Kenyan MBA Programs. International Journal of Innovative Research \& Development, 4(12), 195-205.

Katulwa, B. (2016). Enhancing leadership development in Kenya MBA programs. Anchor Academic.

Katz, R. L. (1974). Skills of an effective administrator. Harvard Business Review, 52(5), 90-102, September/October.

Kinghorn, B. H. \& Black, J. A. \& Oliver, R. (2015). Leadership roles and organizational environment: relationships between competing values. https://www.researchgate.net/publication/260347192 Date of access: 10 May 2017.

Lanier, P., Tanner, J., Zhu, Z. \& Heady, R. (1997). Evaluating instructors' perceptions of students' preparation for management curricula. Journal of Education for Business, 73(2), 77-84.

Lindquist, E. A. \& Marcy, R. T. (2014). The Competing Values Framework: Strategic implications for leadership, conflict and change in public organizations. International Journal of Public Leadership, 12(2), 167-186.

Llopis, G. (2013). Personal branding is a leadership requirement, not a self-promotion campaign. Forbes Leadership. https://www.forbes.com/forbes/welcome/?toURL=https://www.forbes.com/sites/glennllopis/201 3/04/08/personal-branding-is-a-leadership-requirement-not-a-self-promotioncampaign/\&refURL=https://www.google.co.za/\&referrer=https://www.google.co.za/ Date of access: 12 May 2017.

MacMillan, P. (2001). The performance factor: Unlocking the secrets of teamwork. Nashville, TN: B\&H Group.

Maitland, R. \& Anderson-Terry, B. (2017). Preparing leaders for the fourth industrial revolution. http://www.usb-ed.com/WatchReadListen/Pages/Preparing-leaders-for-the-fourth-industrialrevolution.aspx\#BuHYiSei4ZD0qSBu.99 Date of access: 10 August 2017. 
Makulova, A. T., Alimzhanova, G. Y., Bekturganova, Z., Umirzakova, Z. A., Makulova, A. M. \& Karymbayeva, K.M. (2015). Theory and Practice of Competency-Based Approach in Education. International Education Studies, 8(8), 183-192.

Manyika, J. (2017). The Fourth Industrial Revolution is about empowering people, not the rise of the machines. https://www.weforum.org/agenda/2017/06/the-fourth-industrial-revolution-is-aboutpeople-not-just-machines Date of access: 11 August 2017.

Mathews, C. \& Gandall, S. (2015). The 5 biggest corporate scandals of 2015. Fortune: Leadership. http://fortune.com/2015/12/27/biggest-corporate-scandals-2015/ Date of access: 10 May 2017.

McCauley, C. \& Van Velsor, E. (2004). The Centre for Creative Leadership: Handbook for Leadership Development. $2^{\text {nd }}$ ed. San Francisco, CA: Wiley.

Nanterme, P. (2016). Leadership in the $4^{\text {th }}$ Industrial Revolution. http://www.stantonchasemontreal.com/en/industry-40-leadership/ Date of access: 10 May 2017.

Northouse, P. G. (2016). Leadership: Theory and Practice. $7^{\text {th }}$ ed. Thousand Oaks, CA: Sage.

Oritz, J. (2004). International business education in a global environment: A conceptual approach. International Education Journal, 5(2), 255-265.

Ovans, A. (2015). How emotional intelligence became a key leadership skill. Harvard Business Review (28 April). https://hbr.org/2015/04/how-emotional-intelligence-became-a-key-leadership-skill Date of access: 13 May 2017.

Reese, R. (2016). Conflict management competency. http://conflictmanagementworkshops.com/conflictmanagement-article.htm Date of access: 10 May 2017.

Plachy, K. (2015). Managerial maturity. The Leadership Coach. http://www.leadershipcoachllc.com/ Date of access: 6 June 2015.

Roebuck, D. (2001). Improving business communication skills. Upper Saddle River, NJ: Prentice-Hall.

Rogers, E. M. \& Blonski, D. (2010). The global leadership mindset. The Chief Learning Officer, http://webcache.googleusercontent.com/search?q=cache:s-zOXbX6xK0J:ww.w.cedmaeurope.org/newsletter\%2520articles/Clomedia/The\%2520Global\%2520Leadership\%2520Mindset $\% 2520(J u n \% 252010) . p d f+\& c d=1 \&$ hl=en\&ct=clnk\&client=firefox-b-ab

Sanchez, R. \& Heene, A. (2004). Reinventing strategic management: new theory and practice for competencebased competition. European Management Journal, 15(3), 303- 17.

Satija, K. C. (2009). What kind of leadership model would be required to create vision, mission and directions in the changing global context? Advances in Management, 2(12), 25-33, December.

Schwab, K. (2016). Leadership Challenges of the Fourth Industrial Revolution. June 22, 2016. http://www.weform.org/agenda/2016/06/leadership-challenges-of-the-fourth-industrialrevolution/ Date of access: 10 May 2017.

Shaikh, A. (2013). Management competence measurement for business school educated managers. (Dissertation - MBA). Durban: Management College of South Africa.

Shaikh, A. S. C., Karodia, Y. \& Soni, P. (2016). Wake up and stop SA from being stolen. The Sunday Tribune, 20, 27 March.

Simpson, R. (2006). Masculinity and management education: Feminizing the MBA. Academy of Management Learning and Education, 5(2), 182-193.

Stein, S. J. (2017). The EQ Leader: Instilling passion, creating shared goals, and building meaningful organizations through emotional intelligence. New York, NY: Wiley.

Sulaiman, A. \& Mohezar, S. (2009). Quality in an MBA program: Students perceptions. International Journal of Management $\quad$ Education, $\quad 7(2), \quad 1-8$. http://web.ebscohost.com/ehost/pdfviewer/pdfviewer?sid=8d9c43a9-d459-4837-980edfe447b01a00\%40sessionmgr113\&vid=1\&hid=106 Date of access: 4 Aug 2016.

Sulaiman, A. \& Mohezar, S. (2006). Student success factors: Identifying key predictors. Journal of Education for Business, 81(6), 328-333.

Swartz, L. \& Potgieter, C. A. (2017). Work stress, -burnout and organizational politics: perceptions and experience of senior managers in the South African Government sector. Review of Public Management, 5(200). https://www.omicsonline.org/open-access/work-stress-burnout-andorganizational-politics-perceptions-and experience-of-senior-managers-in-the-south-africangovernment-secto-2315-7844-1000200.php?aid=86203 Date of access: 10 May 2017.

Tanyel, F., Mitchell, M. \& McAlum, H. (1999). The skill set for success of new business school graduates: Do prospective employers and university faculty agree? Journal of Education for Business, 75(1), 33-37. 
Takahashi, A. R. W., Bulgacov, S., Bitencourt, C. C. \& Kaynak, H. (2017). Expanding the dynamic capabilities view: special contributions. Revista de Administração de Empresas, $57(3)$. http://www.scielo.br/scielo.php?script=sci_arttext\&pid=S003475902017000300209\&lng=pt\&nrm=iso Date of access: 10 May 2017.

Thekiso, T. A. (2011). Management skills measurement of business school educated managers in the North West and Vaal triangle areas. (Thesis - PhD). Potchefstroom: North-West University.

Thomas, C., Schleifer, K., Sullivan, T. \& Murdough, T. (2014). Managing the profitable construction business: the contractor's guide to success and survival strategies. New York, NY: Wiley.

Truxillo, D. M., Bauer, T. N. \& Erdogan, B. (2016). Psychology and work: Perspectives on industrial and organizational psychology. New York, NY: Routledge.

Tubbs, S. L. \& Schulz, E. (2006). Exploring a taxonomy of global leadership competencies and metacompetencies. The Journal of American Academy of Business, 8(2), 489-499, March.

Walker, D. M., Walker, T. \& Schmitz, J. (2003). Doing business internationally. New York, NY: McGraw-Hill.

Whetten, D. A. \& Cameron, K. S. (2015). Developing management skills. Upper Saddle River, NJ: Pearson Education.

Wiemann, J. M. (1977). Explication and test of a model of communication competence. Human Communication Research, 3, 361-370.

Wiley-Cordone, J. (2016). What are conceptual skills in management? http://study.com/academy/lesson/what-are-conceptual-skills-in-management-definition-lessonquiz.html Date of access: 10 May 2017.

Yukl, G. (2006). Leadership in organizations. $6^{\text {th }}$ ed. Upper Saddle River, NJ: Pearson Prentice Hall. 